\title{
BUDDHISM, MODERNITY, AND THE StATE IN ASIA
}


This page intentionally left blank 


\title{
Buddhism, Modernity, ANd The State in Asia
}

\author{
Forms OF ENGAGEMENT
}

\author{
Edited by \\ John Whalen-Bridge and \\ Pattana Kitiarsa
}

\section{palgrave macmillan}


ISBN 978-1-349-46200-1 ISBN 978-1-137-32617-1 (eBook)

DOI 10.1007/978-1-137-32617-1

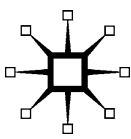

BUDDHISM, MODERNITY, AND THE STATE IN ASIA

Copyright @ John Whalen-Bridge and Pattana Kitiarsa, 2013.

Softcover reprint of the hardcover 1st edition 2013 978-1-137-33294-3

All rights reserved.

First published in 2013 by

PALGRAVE MACMILLAN ${ }^{\circledR}$

in the United States-a division of St. Martin's Press LLC,

175 Fifth Avenue, New York, NY 10010.

Where this book is distributed in the UK, Europe and the rest of the world, this is by Palgrave Macmillan, a division of Macmillan Publishers Limited, registered in England, company number 785998, of Houndmills, Basingstoke, Hampshire RG21 6XS.

Palgrave Macmillan is the global academic imprint of the above companies and has companies and representatives throughout the world.

Palgrave ${ }^{\circledR}$ and Macmillan ${ }^{\circledR}$ are registered trademarks in the United States, the United Kingdom, Europe and other countries.

ISBN: 978-1-137-33294-3

Library of Congress Cataloging-in-Publication Data is available from the Library of Congress.

A catalogue record of the book is available from the British Library.

Design by Newgen Knowledge Works (P) Ltd., Chennai, India.

First edition: July 2013

109876554321 
Dedicated to Pattana Kitiarsa, 1968-2013

Pattana Kitiarsa, who has died at 45, was an exceptional, inspiring yet humble scholar. Born in Nong Khai, a northeastern province in Thailand, Pattana joined the Department of Southeast Asian Studies, National University of Singapore, in

2007. He was an exemplary colleague who selflessly gave of himself to students and coworkers. During his life he worked tirelessly to produce an enormous number of works, in Thai and English, and established himself as a respected scholar of popular Buddhism and transnational migration. His publications helped propel the cultural lifeworlds of Thai magical monks, migrant workers, and Muay Thai boxers into prominence in international academic debates. Battling illness be completed his last book, Medium, Monks, \& Amulets, which came out less than three months before his death. What is even more spectacular is how Pattana was devoted to community service for the benefit of Thai migrant workers in Singapore. Even his deteriorating health by late 2012 did not stop him from his volunteerism, a reason why the Thai migrant community turned out in full force to pay their respects during his wake. Pattana will be greatly missed but his life, deeds, and scholarship will live on in our hearts and minds. He is survived by wife, Rungnapa, daughter,

Nanrawee, and son, Tantham, aged 15 and 13 respectively. 
This page intentionally left blank 


\section{Contents}

Introduction: "Buddhist Politics" as Emptiness: History and the Forms of Engagement in Asia

John Whalen-Bridge and Pattana Kitiarsa

\section{Part I Dependent Originations and Changing Destinations}

1 Buddhists Confront the State

Charles F. Keyes

2 "Foremost among Religions": Theravada Buddhism's Affairs with the Modern Sri Lankan State Mahinda Deegalle

3 Schools, Ritual Economies, and the Expanding State:

The Changing Roles of Lao Buddhist Monks

as "Traditional Intellectuals"

Patrice Ladwig

\section{Part II The Political Role of Sacred Things}

4 Post-Pol Pot Cambodia and the Building of a New Stupa John Amos Marston

5 The Relic and the Rule of Righteousness: Reflections on U Nu's Dhammavijaya

Tilman Frasch

6 Sacred Site or Public Space? The Shwedagon

Pagoda in Colonial Rangoon

Donald M. Seekins 


\section{Part III Monks, Nuns, and... Trees}

7 Angry Monk Syndrome on the World Stage: Tibet, Engaged Buddhism, and the Weapons of the Weak

John Whalen-Bridge

8 Rebirth Control: Contemporary Inner Mongolian Buddhism and the Religious Authority of the

Chinese State

Jonathan Mair

9 Do Buddhist "Nuns" Need the Thai Sangha?

Monica Lindberg Falk

10 Sacred Protests and Buddhist Environmental Knowledge 245 Susan M. Darlington 